Mariusz Olejniczak, Pawet Pliszka

\title{
RESEARCH ON VALUE CO-CREATION WITH THE PARTICIPATION OF PATIENTS BASED ON DART MODEL - METHODOLOGICAL REMARKS
}

\author{
BADANIE WSPÓŁTWORZENIA WARTOŚCI ZDROWOTNYCH Z UDZIAŁEM \\ PACJENTÓW PRZY WYKORZYSTANIU MODELU DART - UWAGI \\ METODOLOGICZNE
}

Akademia Leona Koźmińskiego

\begin{abstract}
INTRODUCTION. Derived from business practices co-creation theory indicates that patient can be a source of value and actively contribute to it.

METERIAL AND METHODS. DART model - most popular conceptualizing framework for value creation - was presented. Considering the multiplicity of perspectives of a large stakeholders group appearing in the healthcare system a direction of its development was also proposed.

AIM. The possibility of using quantitative methods to study value creation between empowered patients and selected stakeholders was tested as well as work of the questionnaire that was adapted from value creation research based on the DART model that was conducted among entrepreneurs.

RESULTS. Substantial number of inadequate questions in relation to the respondents' experience was indicated on the other hand the need to include further groups of stakeholders was emphasized. The results signal the possibility of significant differences in the perception of meeting the requirements for co-creating value with patients by individual stakeholders, such as: doctors, state offices or pharmaceutical companies.

DISCUSSION. Different perception of value makes difficult to find universal tools for measuring it. However, the economic and humanitarian importance of the issue in the healthcare system necessitates such tools further development.

CONCLUSIONS. The tested tool has limited application in the healthcare system but may provide valuable information on the relationship between the patient and doctor or other stakeholder pairs as well as in selected contexts of co-creation.
\end{abstract}

Keywords: value co-creation. DART model, empowered patient

\section{STRESZCZENIE}

WSTĘP. Zaczerpnięta z praktyk biznesowych, teoria współtworzenia wartości wskazuje, że pacjent może być źródłem wartości i aktywnie ją współtworzyć.

MATERIAŁ I METODY. Zaprezentowano będący najpopularniejszą ramą konceptualizacji współtworzenia wartości model DART i zaproponowano kierunek jego rozwoju uwzględniający mnogość perspektyw licznej grupy interesariuszy występujących w systemie opieki zdrowotnej.

CEL PRACY. Testowano możliwość wykorzystania metod ilościowych badania współtworzenia wartości między upodmiotowionymi pacjentami a wybranymi interesariuszami w oparciu o model DART oraz kwestionariusza zaadoptowanego z badań współtworzenia wartości u przedsiębiorców .

WYNIKI. Respondenci wskazywali dużą liczbę nieadekwatnych pytań względem doświadczeń wynikających z odgrywanej przez nich roli, z drugiej strony mocno akcentowali potrzebę ujęcia kolejnych grup interesariuszy. Wyniki sygnalizują możliwość istnienia znaczących różnic w postrzeganiu spełnienia wymogów dla współtworzenia wartości z pacjentami przez poszczególnych interesariuszy jak np.: lekarzy, urzędy państwowe czy też firmy farmaceutyczne. 
DYSKUSJA Różna percepcja wartości powoduje, iż trudno o uniwersalne narzędzia jej pomiaru. Ekonomiczna jak i humanitarna doniosłość współtworzenia wartości w systemie opieki zdrowotnej powoduje konieczność dalszego rozwoju i doskonalenia tych narzędzi.

WNIOSKI Testowane narzędzie posiada ograniczone zastosowanie w systemie opieki zdrowotnej, może jednak dostarczać cennych informacji na temat relacji zachodzących pomiędzy pacjentem a lekarzem lub innymi parami interesariuszy, a także w zakresie wybranych kontekstów współtworzenia.

Słowa kluczowe: wspóttworzenie wartości, model DART, upodmiotowienie pacjenta

\section{INTRODUCTION}

The most common area in which the theory of value co- creation is developed is services but it is also applied in innovation management and marketing research (1). This results from the conviction that value co-creation is not possible without the participation of consumers (2) as this would lead to the co-destruction of value (3). Co-production, prosumption or open (collaborative) innovation include distinctive elements of value co-creation but do not fully encompass the concept (4). The theory of value co-creation states that the consumer may not only be a source of value for a company, but by supplying knowledge (5), or interacting, can actively co-create it. Also, in the case of healthcare related services, value cannot be created without the patient (6) who can take on different roles; ' a customer, a consumer, a competence provider, a controller of quality, a co-producer (7), thus increasing value and influencing personal well-being (8). Effective management of such a process appears to be difficult to achieve without developing proper research tools first.

It is accepted that value is co-created by its beneficiaries when all participating stakeholders derive value from their interactions. The term "platform" may refer to any place where actors can interact and exchange resources to co-create value, both offline and online. Platform performance is not technologically determined, but depends on proper design, including tasks assignment, selection of actors and their involvement; however it is the use of modern technologies that facilitates communication and promotes content sharing, often determining the shape of platforms (3).

Taking in consideration services perspective of value co-creation it should be recognized that the customer and the patient in the health care system, by cooperating with healthcare providers, can increase value, which in the health care system means their wellbeing (8). However, high level of commitment and shared responsibility are prerequisites for achieving satisfactory results (2). The multitude of perspectives on value co-creation perception inspires to welcome its broad definition as: "A joint process during which

\section{WSTĘP}

Podstawowym obszarem, $w$ jakim rozwijana jest teoria współtworzenia wartości są usługi. Znajduje ona również zastosowanie w zarządzaniu innowacjami oraz badaniach marketingowych (1). Wynika to z przekonania, iż bez udziału konsumenta nie jest możliwe wytworzenie wartości (2), gdyż z pominięciem jego udziału możemy, mieć do czynienia ze wspólną jej destrukcją (3). Współprodukcja, prosumpcja czy otwarta (wspólna) innowacja posiadają określone elementy współtworzenia wartości, lecz nie są jeszcze równoznaczne z jej całościową koncepcją (4). Teoria współtworzenia wartości stanowi, iż klient może być dla firmy nie tylko źródłem wartości, ale przez wykorzystanie jego wiedzy (5), lub też wejście w interakcje, może ją aktywnie współtworzyć, Także w przypadku usług zdrowotnych, tworzenie wartości nie jest możliwe bez pacjenta (6), przy czym może on przyjmować różne role; od „konsumenta, przez dostawcę kompetencji i kontrolera jakości do współproducenta" (7) powiększając wartość i wpływając tym samym na swój „zdrowostan” (8). Efektywne zarządzanie powyższym procesem jawi się jednak trudne do osiągnięcia bez uprzedniego wypracowania dobrych narzędzi jego badania.

\section{MATERIAŁ I METODY}

Zauważa się, iż wartość jest współtworzona przez jej beneficjentów, gdy wszystkie uczestniczące podmioty czerpią wartość ze swoich interakcji. Termin platformy może odnosić się do każdego miejsca, w którym aktorzy mogą współdziałać i wymieniać zasoby, aby tworzyć wspólną wartość, zarówno offline jak i online. Wprawdzie wydajność platform nie jest zdeterminowana technologicznie a zależy od właściwego ich zaprojektowania w tym: określania zadań, doboru aktorów, jak i ich zaangażowania, to wykorzystanie nowoczesnych technologii ułatwia jednak komunikację i sprzyja wymianie treści, wytyczając niejednokrotnie ich ksztalt (3).

Przyjmując usługową perspektywę wspólnego tworzenia wartości należy uznać, iż usługobiorca, a pacjent w systemie opieki zdrowotnej, przez współ- 
value is reciprocally created for each actor (individuals, organizations, or networks). These actors engage in the process by interacting and exchanging their resources with one another. The interactions occur on an engagement platform where each actor share its own resources, integrates the resources provided by others, and potentially develops new resources through a learning process. "(3).

In recent years, patients have been using technological advances in various health aspects more actively (9), which makes their impact on other stakeholders in the healthcare system more significant. This is also the basis of introducing the "empowered patient" concept which Castro described in detail (10). As per the World Health Organization's (WHO) definition this is a subpopulation of high level of selfawareness patients who want to be not only the subject of activity, but as a result of social and technological changes, have acquired the willingness, knowledge and power to co-decide on their own health (11). This definition emphasizes that it is a patient who has been included in the process of value co-creation as part of a wider system in which interactions and communication take place and where experience is created. Systemic approach to the value co-creation implies the need to include other stakeholders in the research, and the number of these stakeholders is much larger than in the case of other services or products.

The DART model established by C. K. Prahalad and V. Ramaswamy is an example of a model which describes the conditions necessary for value cocreation is (6). It also remains the most popular conceptualization framework as well as a valuable guide for implementing the concept of value co-creation with the customer in current marketing literature (12). According to the model, co-creation may occur only when such conditions as dialogue, access, risk assessment (risk / benefit awareness), and transparency are jointly fulfilled. These four interacting elements represent interactions between participants of the value co-creation process, who pursue specific actions whose acceptance and effectiveness are subordinate to the accompanying dialogue. Access enables the use of resources. Risk assessment is associated with the right of participants to have complete information that enables proper assessment of risk and the potential benefits associated with specific decisions. Transparency requires reduction of information asymmetry by ensuring openness and access to resources (4). Dialogue presupposes interactivity, deep commitment and the ability as well as willingness of both parties to act, therefore the middle ground is so often difficult to achieve by two unequal partners. Presence of long-lasting information asymmetry in relationships demands to start co-creation from the pracę z podmiotami opieki medycznej może powiększać wartość, czyli w systemie opieki zdrowotnej, swój „zdrowostan” (8). Warunkiem osiągnięcia zadowalających efektów jest jednak wysoki poziom zaangażowania i współodpowiedzialność (2). Wielość perspektyw spojrzenia na wspólne tworzenie wartości inspiruje do przyjęcia jej szerokiej definicji jako: „wspólnego procesu, podczas którego wartość jest wzajemnie tworzona dla każdego aktora (osoby fizycznej, organizacji lub sieci). Aktorzy angażują się w ten proces poprzez interakcję i wymianę zasobów między sobą. Interakcje występują w obszarze wspólnego zaangażowania, w którym każdy uczestnik udostępnia swoje własne zasoby, integruje zasoby dostarczone przez innych i potencjalnie rozwija nowe zasoby dzięki procesowi uczenia się" (3).

Pacjenci w ostatnich latach aktywniej wykorzystują zdobycze technologiczne w różnych aspektach zdrowotnych (9) przez co m.in. mogą uzyskiwać silniejszy wpływ na innych interesariuszy systemu opieki zdrowotnej. Leży to u podstaw powstania koncepcji „empowered patient”, opisanej dokładniej przez Castro (10), która w thumaczeniu odpowiada pacjentowi „upodmiotowionemu”. Zgodnie z definicją Światowej Organizacji Zdrowia (WHO) - jest to subpopulacja pacjentów o wysokim poziomie samoświadomości, którzy chcą być nie tylko przedmiotem działania, ale w wyniku przemian społecznych i technologicznych, pozyskali chęć, wiedzę i władzę do współdecydowania o własnym zdrowiu (11). Powyższa definicja podkreśla, iż jest to pacjent, który został włączony w proces wspólnego tworzenia wartości będący elementem szerszego systemu, w którym odbywają się interakcje, komunikacja i tworzone jest doświadczenie. Systemowe podejście do współtworzenia wartości implikuje jednak konieczność uwzględnienia w badaniach wielu interesariuszy, których liczba jest znacznie większa niż w przypadku innych usług czy produktów.

Jednym z modeli opisujących warunki konieczne do współtworzenia wartości jest stworzony przez $C$. $K$. Prahalada i V. Ramaswamy model DART (6). W aktualnym piśmiennictwie z zakresu marketingu pozostaje on najpopularniejszą ramą konceptualizacji, jak i cennym przewodnikiem związanym $\mathrm{z}$ wdrażaniem koncepcji współtworzenia wartości z klientem (12). Zgodnie $\mathrm{z}$ jego założeniami, aby współtworzenie mogło wystąpić, konieczne jest łączne spełnienie warunków takich jak: dialog, dostęp, świadomość ryzyka/korzyści, przejrzystość. Te cztery oddziałujące na siebie elementy reprezentują interakcje między uczestnikami procesu, którzy dążą do realizacji określonych działań, a których to akceptacja i skuteczność podporządkowana jest towarzyszącemu dialogowi. Dostęp umożliwia wykorzystanie zasobów. Ocena ryzyka wiąże się natomiast z prawem uczestników do posiadania pełnej 
construction of critical foundations such as access and transparency. In the healthcare system medications, hospital, equipment used as well as the doctor's knowledge certainly matter, but what in the eyes of a patient distinguishes one doctor from another is the experience resulting from cooperation that creates value. It develops during diagnosis and therapy, which should consider all individual patient's conditions (6).

To better understand the phenomena researched, such as the complex and paradoxical nature of organizational life, science often makes use of metaphorical comparisons, which in consequence improve ways of management above previous imaginations and possibilities (13). Taking in consideration multitude co-creation surfaces and perspectives of a large group of stakeholders who have an impact on the patient's well-being as well as the increasingly complex nature of relationships, the authors took a slightly modified perspective of the original model proposed by Prahalad and Ramaswamy (5), (6) recognized that desired condition in health care more precisely than a flat, static rhombus reflects a metaphorical diamond scheme that personify the ideal (perfect condition) (Fig. 1). Its axes are postulated as access and transparency, the top of a platform is dedicated to joint dialogue, at its base is awareness of risk. Individual facets illustrate selected different perspectives of various stakeholders (e.g. payer - health provider) and refer to the levels of micro dialogues leading to understanding, which patients are beneficiary, often taking the role of hostage in situations of problems with achieving them (metaphorical flaws).

\section{OBJECTIVE}

The First International Patient Empowerment Congress was a place where participants of value cocreation met in order to exchange views, knowledge, and experience. This event can be considered a kind of an 'empowerment platform' (3) in the scope of the healthcare system which is the main focus of this paper. This paper presents the results of a pilot research, aimed to test specific tools and quantitative methods to study value co-creation between empowered patients and selected stakeholders in medical services based on the DART model.

\section{MATERIAL AND METHODS}

The term 'pilot studies' refers to its mini version (also known as 'feasibility study') preceding the target study, but also includes detailed pre-testing of specific research instruments, such as a questionnaire or interview schedule (14). This study focused on the testing of the research tool (questionnaire). informacji, która umożliwia prawidłową jego ocenę jak i potencjalnych korzyści wiążących się z określonymi decyzjami. Przejrzystość, nakazuje ograniczenie asymetrii informacji $\mathrm{w}$ drodze zapewnienia otwartości i dostępu do posiadanych zasobów (4). Dialog zakłada interaktywność, głębokie zaangażowanie oraz zdolność i chęć działania obu stron, dlatego płaszczyzna dialogu niejednokrotnie trudna jest do osiągnięcia między dwoma nierównymi partnerami. Długotrwała obecność asymetrii informacji w relacjach powoduje, iż współtworzenie wymaga, aby rozpoczynać je od budowy krytycznych fundamentów, jakimi są dostęp i przejrzystość. W systemie opieki zdrowotnej leki, szpital, używany sprzęt, a także wiedza lekarza z pewnością mają znaczenie, ale to co w oczach pacjenta wyróżnia jednego lekarza od innych, tworząc określoną wartość, to wynikające ze współdziałania doświadczenie. Kształtuje się ono w trakcie rozpoznania, jak i terapii, które winny uwzględniać wszelkie indywidualne uwarunkowania pacjenta (6).

Celem lepszego zrozumienia badanych zjawisk, jak np. złożony i pełen paradoksów charakter życia organizacyjnego, nauka niejednokrotnie posiłkuje się metaforycznymi porównaniami, które w konsekwencji wynoszą sposoby zarządzania ponad wcześniejsze wyobrażenia i możliwości (13). Zważywszy na mnogość płaszczyzn, jak i perspektyw licznej grupy interesariuszy posiadających wpływ na zdrowostan pacjentów oraz coraz bardziej złożony charakter występujących relacji, autorzy przyjęli nieco zmodyfikowaną perspektywę pierwotnego modelu, jaki zaproponowali Prahalad'a i Ramaswamy'a (5), (6) uznając, iż pożądany stan w ochronie zdrowia precyzyjniej od płaskiego, statycznego rombu oddaje metaforyczny schemat brylantu, uosabiający ideał (stan idealny) (Rys. 1). Jego osią jest postulowany dostęp i przejrzystość, zwieńczeniem płaszczyzna dedykowana wspólnemu dialogowi, u jego podstaw stoi świadomość ryzyka. Poszczególne fasety obrazują natomiast odmienne perspektywy różnych interesariuszy (np. płatnik - świadczeniodawca) i nawiązują do płaszczyzn mikro dialogów prowadzących do porozumień, których pacjent jest beneficjentem, przyjmując niejednokrotnie role zakładnika w sytuacji problemów z ich osiągnięciem (metaforyczna skaza).

\section{CEL PRACY}

Pierwszy Międzynarodowy Kongres Empowerment Patient był miejscem, gdzie spotkali się uczestnicy wspólnego tworzenia wartości, dokonując niezbędnej wymiany, poglądów, wiedzy oraz doświadczeń. Uznać można to wydarzenie za rodzaj ,platformy upodmiotowienia" (3) w interesującym autorów, systemie opieki zdrowotnej. 


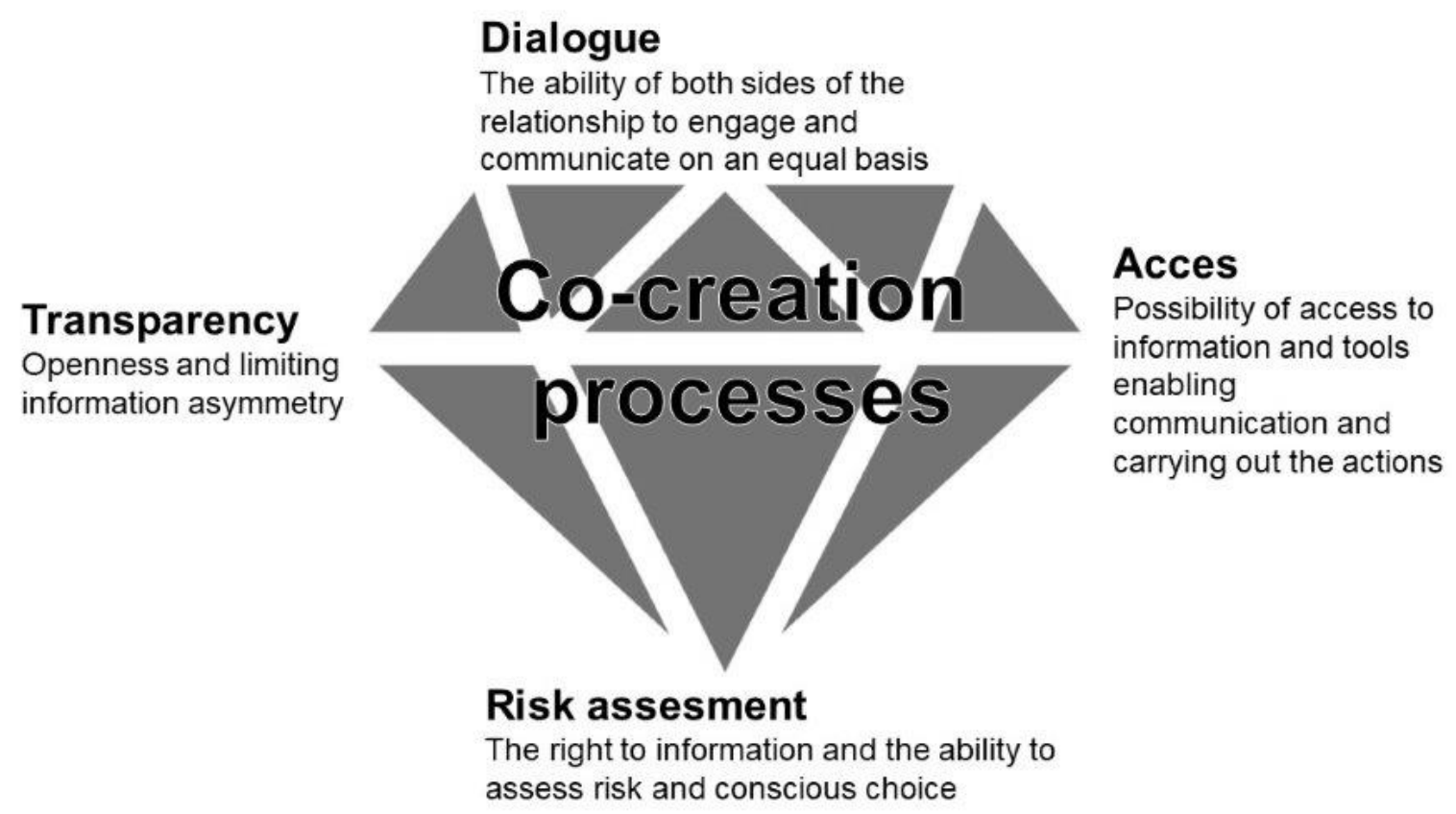

Fig. 1 Diamond of health value co-creation

Rys. 1 Brylant współtworzenia wartości w systemie opieki zdrowotnej

It is a response the demand for further research on 'engagement platforms': platforms for broadly understood dialogue for patient empowerment and stakeholder roles in value co-creation (3), as well as testing questionnaires in a population as close to the target one as possible, and to share results from pilot studies (14). Three methods were used together in the pilot study: the questionnaire , observations, and interviews with respondents (15). The interviews, as well as the observation, helped to assess the questionnaire. The research was based on assumptions and tools which Mazur and Zaborek (12) used to study the DART model in Polish entrepreneurs in which they used quantitative methods.

For research purposes, a questionnaire with the Likert scale with increased sensitivity was prepared, where the value 1 corresponds to "strongly disagree", through a milder "disagree", "more or less disagree" and contained in the middle of its "I have no opinion" up to "strongly agree" in item 7 through: "rather more or less agree" 5 and "agree" 6 . The main difference from the Mazur and Zaborek approach lies in the form of a pilot study, which was enriched with qualitative elements - open questions aimed at assessing the tool. The questionnaire has been methodologically consulted with industry sector experts, including medical ones, in order to adapt its substantive content to the needs of the study with patients, while maintaining an unchanged nature of the questions. So, the burden of the study was shifted from obtaining data that allows assessing the fulfillment of the conditions for joint value creation with patients, to the methodological aspects of the proposed actual study.
Artykuł przedstawia wyniki pilotażowego badania ankietowego, którego celem było testowanie konkretnych narzędzi i metod ilościowych do badania współtworzenia wartości między upodmiotowionymi pacjentami a wybranymi interesariuszami w usługach medycznych, tworzonych w oparciu o model DART.

Termin „badania pilotażowe” odnosi się do poprzedzającej wykonanie właściwego badania jego mini wersji (znanej także jako „studium wykonalności”), obejmuje jednak także szczegółowe testy wstępne poszczególnych instrumentów badawczych, takich jak kwestionariusz czy harmonogram wywiadów (14). Przeprowadzone badanie, dotyczyło testowania narzędzia badawczego (kwestionariusza). Jest ono odpowiedzią na zgłaszany postulat realizacji dalszych badań nad „engagement platform”, czyli platformami szeroko rozumianego dialogu na rzecz upodmiotowienia lub rzecz ujmując inaczej upełnomocnienia pacjenta i rolą uczestników wspólnego tworzenia wartości (3), a także testowania kwestionariuszy w populacji możliwie zbliżonej do badanej oraz dzielenia się wynikami z badań pilotażowych (14). W przeprowadzonym pilotażu zastosowano łącznie trzy metody; badany kwestionariusz, obserwacje oraz wywiad $\mathrm{z}$ ankietowanymi (15). Wywiad, podobnie jak i obserwacja, służyły ocenie pracy kwestionariusza. Badanie ankietowe było oparte na założeniach i narzędziach, jakie wykorzystali Mazur i Zaborek (12) w badaniu modelu DART u polskich przedsiębiorców, w którym wykorzystali oni metody ilościowe. Na jego potrzeby przygotowano ankietę w której wykorzystano skalę Likerta o zwiększonej czułości, gdzie wartość 1 odpowiada „zdecydowanemu nie”, poprzez łagodniejsze „,nie”, ,raczej nie” i zawarte w środkowej jej części „nie mam zdania” ku „zdecydowanemu 
The following three research questions were posed:

Q1: Are quantitative methods appropriate and sufficient to research off-line empowerment platforms?

Q2: Can the survey and modified questions developed for the purpose of researching the relationship between two parties (entrepreneurs customers) be properly applied to assess the value of co-creation between many stakeholders?

Q3: Can the survey and the modified questions developed for the needs of business research be properly applied to assess the value of co-creation in the healthcare system?

Interviews with participants focused on the construction of questions, especially those which were difficult to understand by the responders or with which the responders had some technical issues when answering. The necessity of such verification at the pilot stage is strongly emphasized in literature. The nature and size of the population of the study was not intended to be representative (15), therefore there was no estimation of the sample size necessary to demonstrate statistical significance.

\section{RESULTS}

Amongst 466 registered congress participants, 57 agreed to complete the survey (15). The results collected during survey contain significant information and allow to answer the third of the research questions, therefore they were presented later (Table I). However, due to the absence of an external reference point, it is difficult to compare the data with results of similar research, also generalization cannot be taken into consideration due to the methodology applied. Thanks to the WilcoxonMann-Whitney test in the version developed by Marx et al. (16), on the other hand, it was possible to compare the assessment of value co-creation within the studied groups. This comparison was made between pairs: doctors - public offices and doctors - pharmaceutical companies. In some questions, this test allowed to show statistically significant differences in the perception of meeting the requirements for co-creating value with patients in the above-mentioned pairs, which was also presented in the Results (Table I).

As for the assessment of the research tool itself, the respondents instead reported the following:

'The questions are quite difficult, detailed, the answers are based on my experience as a "patient", may not be the same as the actual information, e.g. information available on the websites of the Office or various pharmaceutical companies' - Representative of a Pharmaceutical company

'Even as a patient, my opinions on general practitioners and specialists are different' - Without identification (exact citation) tak” w pozycji 7 poprzez: „raczej tak” 5 i „tak” 6. Podstawowa różnica względem podejścia Mazur i Zaborek leży w formie badania pilotażowego, które wzbogacone zostało o elementy jakościowe - otwarte pytania nakierowane na ocenę zastosowanego narzędzia. Ankieta użyta w badaniu została uprzednio poddana konsultacjom metodologicznym z ekspertami branżowymi, w tym także z branży medycznej celem dostosowania jej zawartości merytorycznej do potrzeb badania $z$ udziałem pacjentów, przy zachowaniu możliwie niezmienionego charakteru pytań. Ciężar badania został tym samym przesunięty z pozyskiwania danych pozwalających na ocenę spełnienia warunków wspólnego tworzenia wartości z pacjentami, na aspekty o charakterze metodologicznym projektowanego badania właściwego. Postawiono przy tym trzy następujące pytania badawcze:

P1: Czy metody ilościowe są metodami odpowiednimi i wystarczającymi do badania platform upodmiotowienia (typu off-line)?

P2: Czy ankieta i zmodyfikowane pytania opracowane na potrzeby badania relacji, między dwoma stronami (przedsiębiorca - klient) mogą mieć właściwe zastosowanie do oceny współtworzenia wartości pomiędzy wieloma interesariuszami?

P3: Czy ankieta i zmodyfikowane pytania opracowane na potrzeby badania przedsiębiorców mogą mieć właściwe zastosowanie do oceny współtworzenia wartości w systemie opieki zdrowotnej?

Wywiady z uczestnikami skupiały się na konstrukcji pytań, uszczegóławiając później te, które budziły wątpliwości we właściwym ich zrozumieniu przez ankietowanych lub były problematyczne w kwestiach technicznych związanych z udzielaniem odpowiedzi. Konieczność podejmowanych weryfikacyjnych działań na etapie pilotażu została silnie uwypuklona w literaturze. Specyfika i wielkość populacji przeprowadzonego badania z założenia nie była reprezentatywna (15), dlatego nie wykonano szacowania próby niezbędnej do wykazania znamienności statystycznej.

\section{WYNIKI}

Pośród 466 zarejestrowanych uczestników, 57 zdecydowało się na wypełnienie ankiety (15). Wyniki $\mathrm{z}$ ankiet wnoszą na tyle istotne informacje względem możliwości odpowiedzi na trzecie z pytań badawczych, iż zostały ujęte i przedstawione (Tab. I). Ze względu na brak zewnętrznego punktu odniesienia trudno jest jednak odwołać się do innych zbliżonych wyników badań, nie wspominając, ze względów metodologicznych, na możliwość ich generalizowania. Dzięki zastosowaniu testu Wilcoxona-Manna-Whitneya w wersji opracowanej przez Marx i in. (16) można było natomiast wykonać porównanie oceny współtworzenia wartości w obrębie badanych grup. Porównanie to zostało wy- 
'A large proportion of the interactions you are asking about in the survey does not exist, but probably they are not needed'- Patient Representative

The use of questions for three different groups of stakeholders on a 7-point scale in the paperbased survey created an unnecessary burden for the responders, which was confirmed by a significant number of unanswered questions (Table I). konane pomiędzy parami: lekarze - urzędy państwowe oraz lekarze - firmy farmaceutyczne. W części pytań test ten pozwolił na wykazanie statystycznie znaczących różnic w postrzeganiu spełnienia wymogów dla współtworzenia wartości $\mathrm{z}$ pacjentami w wymienionych powyżej parach, co zostało także ujęte w wynikach (Tab. I).

Tabela. 1. The group stakeholder to which each statement relates

Table. 1. Wyniki badania ankietowego z wykorzystaniem badanego narzędzia w badaniu pilotażowym

\begin{tabular}{|c|c|c|c|c|c|c|c|c|}
\hline & 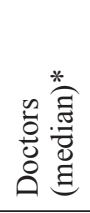 & 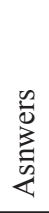 & 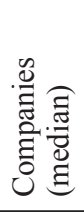 & 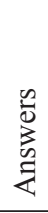 & 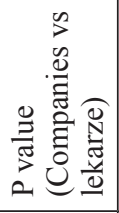 & 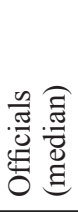 & $\begin{array}{l}\bar{N} \\
\frac{0}{0} \\
\frac{0}{3} \\
0 \\
\frac{0}{0}\end{array}$ & 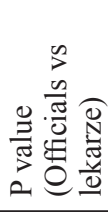 \\
\hline maintain two-way communication with patients regarding therapy. & 3 & 56 & 3 & 56 & 0,111 & 2 & 56 & 0,001 \\
\hline $\begin{array}{l}\text { encourage patients to ask questions and provide feedback that leads to an } \\
\text { increase in their therapy experience. }\end{array}$ & 3 & 57 & 2 & 55 & 0,891 & 2 & 56 & 0,054 \\
\hline $\begin{array}{l}\text { give patients great opportunities to share ideas to increase their satisfac- } \\
\text { tion with therapy. }\end{array}$ & 2 & 57 & 2 & 55 & 0,625 & 2 & 55 & 0,547 \\
\hline maintain one-way communication with patients. & 5 & 54 & 4,5 & 52 & 0,078 & 5 & 52 & 0,804 \\
\hline $\begin{array}{l}\text { maintain online forums where patients can exchange opinions with them } \\
\text { and with each other. }\end{array}$ & 3 & 53 & 4 & 53 & 0,037 & 2 & 51 & 0,239 \\
\hline support the dissemination of information for patients on third-party websites. & 3 & 50 & 3 & 51 & 0,134 & 2 & 51 & 0,119 \\
\hline The online media provide sufficient amount of information to patients about. & 3 & 52 & 3 & 52 & 0,267 & 3 & 52 & 0,206 \\
\hline freely inform patients about the possible risk of using therapy. & 3 & 51 & 3,5 & 50 & 0,865 & 2,5 & 50 & 0,006 \\
\hline $\begin{array}{l}\text { encourage patients to read the warnings about the dangers and other risks } \\
\text { associated with therapy. }\end{array}$ & 3 & 50 & 3,5 & 50 & 0,758 & 3 & 50 & 0,092 \\
\hline advise patients how to use the therapy to avoid various risks. & 4 & 51 & 4 & 48 & 0,449 & 3 & 50 & 0,002 \\
\hline provide patients with all relevant information to facilitate the use of therapy. & 3 & 51 & 3 & 50 & 0,711 & 3 & 50 & 0,097 \\
\hline $\begin{array}{l}\text { Partner relations with patients, encouraging them to provide information } \\
\text { that can improve the experience of therapy. }\end{array}$ & 4 & 51 & 4 & 53 & 0,441 & 3 & 53 & 0,046 \\
\hline $\begin{array}{l}\text { provide patients with up-to-date information, which contributes to the best } \\
\text { experience of therapy. }\end{array}$ & 3 & 55 & 3 & 53 & 0,786 & 2 & 52 & 0,002 \\
\hline
\end{tabular}

On the other hand, the respondents emphasized the necessity for including even more stakeholders, stating as below:

'The survey does not include nurses or midwives, who, in accordance with applicable law, may also play an important role in the prevention, treatment, education of the patient and family'- Nurse.

'The medical community consists not only of doctors and more professions need to be included: nurses, pharmacists, laboratory technicians, paramedics, nutritionists, physiotherapists'-Employer representative

'There is a lack of perspective of other groups in the healthcare system (IT, ICT. Medical Devices) of other scientific environments' - Employer representative

\section{DISCUSSION}

Previous attempts to study value co-creation with the use of the DART model were focused in most cases
W odniesieniu do oceny samego narzędzia badawczego ankietowani zgłaszali natomiast następujące uwagi:

„Pytania sa dość trudne, szczególowe, odpowiedzi opieraja się na moim doświadczeniu jako „pacjent”, moga nie pokrywać się ze stanem faktycznym np. informacjami dostępnymi na stronach urzędu, różnych firm farmaceutycznych" - Przedstawiciel firmy farmaceutycznej

„Nawet jako pacjent inne mam opinie o lekarzu pierwszego kontaktu, a inne o specjalistach o różnych też różne" - Bez identyfikacji (cytowanie doktadne),

„Duża część interakcji, o które pytaja Państwo $w$ ankiecie nie wystepuje, ale prawdopodobnie nie sa potrzebne" - Przedstawiciel pacjentów,

Umieszczanie pytań dla 3 grup interesariuszy w 7-stopniowej skali, w papierowej wersji ankiety, okazało się zbyt obciążające, co potwierdza znaczna liczba pytań pozostawionych bez odpowiedzi (Tab. I), 
on using qualitative research methods. However, it could be researched using quantitative methods and an example of such is the study of Polish entrepreneurs by Mazur and Zaborek (12). It is also worth noticing that value co-creation studies in healthcare are usually of limited and conceptual nature (17). These studies are dominated by research in broadly understood public sector as well as single and multiple case studies (18).

Co-creation transforms the market and its perception into forums where a dialogue between consumers, companies, consumer communities, and company networks may take place. This dialogue, in combination with access and transparency, allows the consumer to assess the benefits of actions and decisions (6). Value creation is a certain "surplus (valor plus), enriching the product offer, correlated with the market value of the organization that produces this value" (8). Because of the diversity of value creation processes, as well as its different perception among recipients, it is difficult to create a universal measuring tool (4). Nevertheless, many aspects speak on behalf of the importance of such research; ranging from humanitarian to strictly economic, such as 'the health outcomes achieved per dollar spent'19). However, the process of value co-creation cannot be simplified only to economic relations, e.g. between supply and demand (8).

\section{CONCLUSIONS}

A testing method used for value co-creation with clients, based on the DART model, as well as the model itself, could be used for testing value creation with patients but with limitations. It should be noted that the tested research tool to a limited extent describes the value co-creation between patients and multiple stakeholders of healthcare system, which indicates the need of its further improvement. Primarily it allows to research value co-creation in a limited number of dimensions, e.g. the relations between the patient and the physician or in other dyads of stakeholders. The patient, however, is a part of a wider system, in which interactions, communications, and experiences are created. This makes it necessary to include multiple perspectives of different stakeholders in the study. These perspectives may not be similar as they are not free from various external influences and often are the result of different priorities, which is reflected in the metaphor of a diamond with a perfectly brilliant cut, which is worth achieving and should be sought.

To be expected though, that postulated inclusion of further stakeholder groups increase the number of questions inadequate to the experience of respondents from different groups. This limits the possibility of utilization of the tested survey as a research tool z drugiej strony respondenci akcentowali konieczną potrzebę ujęcia jeszcze większej liczby interesariuszy, twierdząc jak poniżej:

„Brakuje $w$ ankiecie pielęniarek i położnych, które zgodnie $z$ obowiazującym prawem moga również odgrywać istotna role $w$ profilaktyce, leczeniu, edukacji pacjenta i rodziny" - Pielegniarka.

„Srodowisko medyczne to nie tylko lekarze, potrzeba rozszerzenia o perspektywę innych zawodów: pielegniarki, farmaceuci, laboranci, ratownicy medyczni, dietetycy, fizykoterapeuci" - Przedstawiciel pracodawców

„Brakuje perspektywy innych środowisk $w$ systemie ochrony zdrowia (IT, ICT. Medical Devices) innych środowisk naukowych" - Przedstawiciel pracodawców

\section{DYSKUSJA}

Dotychczasowe próby badania współtworzenia wartości z wykorzystaniem modelu DART w zdecydowanej większości skupiały się na badaniach z użyciem metod jakościowych. Model ten może być jednak badany metodami ilościowymi, czego przykładem są prowadzone badania polskich przedsiębiorców przez Mazur i Zaborek (12). W ochronie zdrowia badania wspóltworzenia wartości posiadają zwykle ograniczony i konceptualny charakter (17). Dominuje w nich reprezentacja szeroko rozumianego sektora publicznego, a także metodologia pojedynczych oraz wielokrotnych studiów przypadków (18).

Współtworzenie przekształca rynek i jego postrzeganie $\mathrm{w}$ rodzaj forum, na którym może mieć miejsce dialog między konsumentem, firmą, społecznościami konsumentów i sieciami firm. W połączeniu z dostępem i przejrzystością pozwalają one konsumentowi na dokonywanie jasnej oceny korzyści wynikających z przebiegu działań jak i podejmowanych decyzji (6). Wytworzenie wartości stanowi pewien, ,naddatek (valor plus), wzbogacający ofertę produktową, skorelowany z rynkową wartością organizacji, która ów walor wytwarza" (8). Z uwagi na różnorodność procesów powstawania wartości, a także odmienną jej percepcję u odbiorców, trudno jednak o stworzenie uniwersalnego narzędzia jej pomiaru (4). Za ważnością przedmiotu badań przemawia wiele aspektów; począwszy od humanitarnego, aż po stricte ekonomiczny, jak np. „efekt zdrowotny osiągnięty w przeliczeniu na dolara" (19). Procesów wspólnego tworzenia wartości nie można jednak uprościć tylko do ekonomicznych relacji np. pomiędzy podażą i popytem (8).

\section{WNIOSKI}

Metoda wykorzystana do badania współtworzenia wartości z klientami opartego na modelu DART jak i sam model, mogą mieć zastosowanie do ba- 
in its existing form and indicates the need for its fragmentation and reedition. In the same manner justifies inclusion of qualitative methods in the value co-creation research together with also limitation of these research to selected dimensions or areas of value co-creation. Supported by the subjectivity and the nature of the experience and provided answers derived from multidimensional nature of value co-creation experiences.

The postulated increase in the number of included stakeholders faces also a number of constrains arising from the legal obligation to preserve the anonymity of participants emerging from the requirement to protect personal data about a sensitive area of life, which is health. This inhibit also the ability to combine data from various engagement platforms. and limits the methods of obtaining a representative sample for reliable quantitative research. A similar challenge is the multiple position of individual subjects, as often they combine role of both patients and people directly or indirectly connected with the healthcare system.

Failure to obtain statistically significant differences in most of the questions may result from the lack of adequate sample size. However, it could not be ruled out that this is a consequence of the inadequacy of questions, which are based on a questionnaire for entrepreneurs and may not fully describe relationships in the health care system, which is also part of the observations noted by the respondents. These findings are also in agreement with the conclusion of Mazur and Zaborek indicating that the DART model may not be an accurate representation of co-creation value practices (12). The canonical area of healthcare for the theory of value co-creation is then not an isolated case of inadequate representation of value co-creation practices. Not every scientist wishes to share the results of work deviating from the assumed hypotheses, which superimposes the identified and scientifically bias of journals to discriminate against zero-score studies (20), (21), (22). However, this information is important because scientists could focus on other more effective methods of investigation, and optimize future research on value co-creation with patients.

\section{REFERENCES}

1. Galvagno M. Dalli D. Theory of value co-creation: a systematic literature review; Managing Service Quality; An International Journal; 2014; 24(6): 643-683

2. Baran G. Marketing współtworzenia wartości z klientem Społecznotwórcza rola marketingu $\mathrm{w}$ procesie strukturacji interakcyjnego środowiska doświadczeń. Kraków, Instytut Spraw Publicznych Uniwersytetu Jagiellońskiego; 2013: 88-89. 103 dań współtworzenia wartości z pacjentami, jednakże w ograniczonym zakresie. Zauważyć należy, iż testowane narzędzie badawcze w ograniczony sposób opisuje współtworzenie wartości między pacjentami a liczną grupą interesariuszy w systemie, co wskazuje na konieczność dalszego jego doskonalenia. Pozwala natomiast na prowadzenie badań współtworzenia wartości w ograniczonej ilości wymiarów np. relacji zachodzących pomiędzy pacjentem oraz lekarzem lub innymi parami interesariuszy. Pacjent jest jednak elementem szerszego systemu, w którym odbywają się interakcje, komunikacja i tworzone jest doświadczenie, co powoduje konieczność uwzględnienia w badaniach wielu perspektyw różnych interesariuszy. Nie zawsze są one zbliżone, gdyż nie są wolne od różnych wpływów zewnętrznych i wynikają niejednokrotnie z odmiennych priorytetów, co odzwierciedla przyjęta metafora diamentu o perfekcyjnie brylantowym szlifie, do którego warto i trzeba dążyć.

Należy spodziewać się, że ujęcie postulowanych kolejnych grup interesariuszy, zwiększy liczbę pytań nieadekwatnych dla doświadczenia respondentów wywodzących się z innych grup. Fakt ten komplikuje możliwość wykorzystania testowanej ankiety jako narzędzia badawczego $\mathrm{w}$ jej istniejącej formie i wskazuje na konieczność jej fragmentacji oraz przeredagowania. Uzasadnione wydaje się także włączenie do przedmiotowych badań metod jakościowych oraz ograniczenie badania do wybranych jego wymiarów lub obszarów współtworzenia wartości. Przemawia za tym subiektywność oraz wynikający z wielowymiarowości współtworzenia wartości charakter doświadczeń i udzielanych odpowiedzi.

Postulowane zwiększenie liczby interesariuszy, napotyka także na szereg ograniczeń, związanych z prawnym obowiązkiem zachowania anonimowości uczestników podyktowanym wymogiem ochrony danych osobowych o wrażliwej strefie życia, jaką jest zdrowie. Utrudnia ono także możliwość łączenia danych z różnych platform współtworzenia, jak i ogranicza sposoby pozyskania reprezentatywnej próby dla realizacji rzetelnych badań ilościowych. Podobnym wyzwaniem jest wieloraka rola poszczególnych badanych, gdyż niejednokrotnie są oni zarówno pacjentami, jak i osobami bezpośrednio lub pośrednio związanymi z systemem opieki zdrowotnej.

Brak uzyskania statystycznie znaczących różnic w większości pytań, może wynikać z braku odpowiedniej wielkości próby. Nie można jednak wykluczyć, że jest to konsekwencja nieadekwatności pytań, które bazują na ankiecie dla przedsiębiorców i mogą nie w pełni opisywać relacji w systemie opieki zdrowotnej, co stanowi także część spostrzeżeń odnotowanych przez ankietowanych. Wnioski te wydają się również pokry- 
3. Leclercq T., Hammedi W, Poncin I. Ten years of value cocreation: An integrative review. w Recherche et Applications En Marketing (English Edition), 2016; 31(3), 26-60.

4. Dziewanowska K. Proces współtworzenia wartości konceptualizacja i wybrane modele badawcze. Studia Oeconomica Posnaniensia, 2018; 6(6): 76-86

5. Prahalad Coimbatore K., and Venkatram Ramaswamy. "Co-opting customer competence." Harvard business review 78.1 2000: 79-90.

6. Prahalad C. K., \& Ramaswamy V. Co-creation experiences: The next practice in value creation. W JOURNAL OF INTERACTIVE MARKETING, 2004; 18(3), 5-14.

7. Matysiewicz J. S. Value Co-Creation in Health Care Networks - International Perspective. W Annales Universitatis Mariae Curie-Skłodowska, Sectio H, Oeconomia, 2017; 51(2), 177-183

8. Rogoziński K. Zarządzanie wartością z klientem. Warszawa: Wolters Kluwer Polska; 2015: 248, 321-4, 326

9. Łaska-Formejster A. Pacjent w sieci zależności. Wydawnictwo Uniwersytetu Łódzkiego; 2015: 327

10. Castro E. M., Van Regenmortel T., Vanhaecht K., Sermeus W., \& Van Hecke A. Patient empowerment, patient participation and patient-centeredness in hospital care: A concept analysis based on a literature review. W Patient Education and Counseling. 2016: 99 (12); 1923-1939

11. WHO Guidelines on Hand Hygiene in Health Care: First Global Patient Safety Challenge Clean Care Is Safer Care. Geneva 2009;

12. Mazur J., \& Zaborek, P. Validating DART Model. Validating DART Model International w J Manag Econom. International Journal Zeszyty Naukowe KGŚ, 2014; 44(44), 106-125.

13. Morgan G. Obrazy organizacji. (Wiankowska-Ładyga; Zofia, Trans.). Warszawa: Wydawnictwo Naukowe PWN, 1997: 10-11

14. van Teijlingen, E. Hundley, V. The importance of pilot studies. Social Research Update, 2001; 35;

15. Grzeszkiewicz-Radulska K. Metody badań pilotażowych. W Acta Universitatis Lodziensis. Folia Sociologica; 2012:(42). 113-141

16. Marx A., Backes C., Meese E., Lenhof H. P., \& Keller A. EDISON-WMW: Exact Dynamic Programing Solution of the Wilcoxon-Mann-Whitney Test. W Genomics, Proteomics and Bioinformatics; 2016: 14 (1): 55-61 wać z konkluzją Mazur i Zaborek wskazującą, że model DART może nie być dokładną reprezentacją praktyk współtworzenia wartości (12). Kanoniczny obszar wspólnego jej tworzenia, jakim jest opieka zdrowotna nie jest zatem odosobniony. Nie każdy naukowiec pragnie dzielić się rezultatami prac odbiegającymi od zakładanych hipotez, na co nakłada się zidentyfikowana i podejmowana naukowo tendencja czasopism do dyskryminowania badań o wyniku zerowym (20), (21), (22). Niemniej informacje takie są istotne, gdyż mogą ukierunkować innych naukowców na bardziej efektywne sposoby dociekań, a także zoptymalizować przyszłe badania dotyczące współtworzenia wartości z pacjentami.

17. Daunt and Martin Kitchener. "Value co-creation through patient engagement in health care: a micro-level approach and research agenda." Public Management Review 17.1 2015: 90-107

18. Voorberg William H., Viktor JJM Bekkers, and Lars G. Tummers. "A systematic review of co-creation and co-production: Embarking on the social innovation journey." Public Management Review 17(9); 2015: 1333-1357

19. Porter M. E. What Is Value in Health Care? w New England Journal of Medicine, 2010; 363(26): 24772481

20. Dickersin K., Chan, S., Chalmersx, T. C., Sacks, H. S., \& Smith, H. . Publication bias and clinical trials. Controlled Clinical Trials, 1987; 8(4): 343-353.

21. Hopewell S., Loudon K., Clarke M. J., Oxman A. D., \& Dickersin K. Publication bias in clinical trials due to statistical significance or direction of trial results. Cochrane Database of Systematic Reviews, 2009; (1)

22. Vawdrey D. K., \& Hripcsak G. Publication bias in clinical trials of electronic health records. Journal of Biomedical Informatics, 2013; 46(1): 139-141.

Received: 7.01.2019

Accepted for publication: 13.08.2019

Otrzymano: 7.01.2019 r.

Zaakceptowano do publikacji: 13.08.2019 r.

Address for correspondence:

Adres do korespondencji:

Mariusz.Olejniczak@interia.pl

pawel.pliszka@interia.pl 